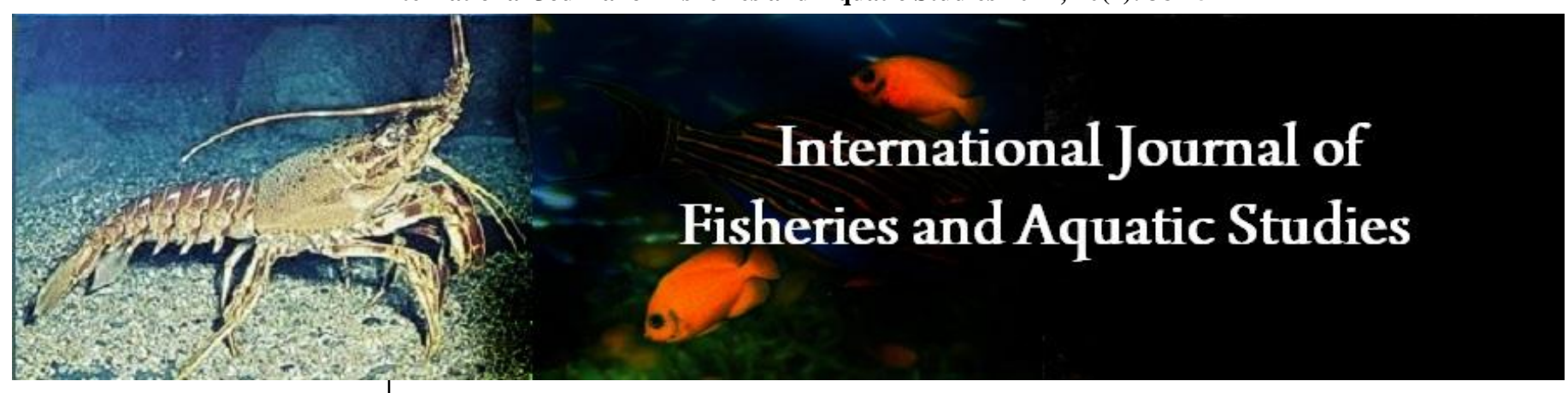

E-ISSN: 2347-5129

P-ISSN: 2394-0506

(ICV-Poland) Impact Value: 5.62

(GIF) Impact Factor: 0.549

IJFAS 2022; 10(1): 38-45

(C) 2022 IJFAS

www.fisheriesjournal.com

Received: 19-11-2021

Accepted: 21-12-2021

Tukura Echuano Eyiseh

Department of Fisheries and

Aquaculture, Federal University

Wukari, Nigeria

Sogbesan Olukayode Amos

Department of Fisheries and

Aquaculture, Federal University

Wukari, Nigeria

Idowu Thomas Adeniyi

Department of Fisheries and

Aquaculture, Federal University

Wukari, Nigeria
Corresponding Author: Tukura Echuano Eyiseh Department of Fisheries and Aquaculture, Federal University Wukari, Nigeria

\section{Incidence of parasitic infection in adult and juvenile Clarias gariepinus in a private fish farm, Yola, Adamawa state}

\author{
Tukura Echuano Eyiseh, Sogbesan Olukayode Amos and Idowu Thomas \\ Adeniyi
}

DOI: https://doi.org/10.22271/fish.2022.v10.i1a.2631

\begin{abstract}
The study was conducted in Gesedaddo's farm, Yola, Adamawa state, Nigeria to determine the prevalence of parasites infecting Clarias gariepinus between June to November, 2016. A total of one hundred and thirty-two (132) fish were sampled for parasitic investigation. Out of these, cultured adults (66) and cultured juveniles (66) respectively were procured from the farm and examined for parasites using the keys of fresh water fish parasite pictorial guide and were examined for parasitic infections using direct wet mount microscopy and stained smears. A total number of 43 adult Clarias gariepinus were infected out of which 132 parasites were identified, while in juvenile Clarias gariepinus, a total number of 10 fish were infected in which 30 parasites were identified in Gesedaddo's farm. Seven (7) classes of parasites and eleven (11) parasite species, which are namely, Piscinoodinium, (Dinoflagellata), Coccidia, Spironucleus vortens, (Flagellata), Chilodonella, Tetrehymena, (Motile ciliate), Capillaria, Contracaecum, (Nematoda), Microsporidians, (Protozoa), Saprolegnia sp, (Oomycota), Digeneans, and Planarian (Trematoda) were recorded from the gills, stomach, intestine, and skin mucus of the cultured Clarias gariepinus on the farm. Parasitic infestation was higher in the intestine with 63 (47.73) and the least was identified 6 (4.55) on the skin for adult Clarias gariepinus while the highest number of parasites identified in juvenile Clarias gariepinus was found on the skin with total number of 11 (36.67). Among the class of parasites identified, it was recorded that the highest parasitic load occurred most in the class protozoan with $45(34.09 \%)$ and 17 (56.67) in adult and Juvenile C. gariepinus respectively. The Chi square value shows that there was no significant difference $(p>0.05)$ between the prevalence and intensity of parasitic infection in adults and juvenile $C$. gariepinus based on sex. Parasitic infestations in the adult and juvenile female were significantly higher than in the adult and juvenile male in cultured Clarias gariepinus. There was a significant difference between incidence of infestation, standard length and body weight of Clarias gariepinus while there was no significant difference ( $>0.05)$ between parasitic load.
\end{abstract}

Keywords: parasitic infection, incidence, Clarias gariepinus, gesedaddo's farm

\section{Introduction}

Fish is one of the significant sources of protein for humans and other animals in the tropics. According to Food and Agricultural Organization, (2003), fish accounts for more than $40 \%$ of the protein diet of two-thirds of the global population. Fish provides food for immediate Consumption and substantial number of people depend on fishing for economic gains and providing jobs. A well- processed fish product from the tropics has a ready market in developed countries and is therefore a good foreign earner (Imam and Dewu, 2010) [18]. Nigeria is among the largest fish consumers in the world with over 1.5 million tonnes of fish consumed annually (Imam et al., 2010) ${ }^{[18]}$. In most part of the world, fish production is mainly from the wild. As the world population grows, fish resources are being depleted at an increasing rate as a result of environmental degradation, over harvesting, pollution thus fish production could no longer meet the demand of the growing population. This had led to increase in the involvement of stakeholders in aquaculture. This method has also been plagued by the problems of overcrowding, poor environmental conditions and pollution which often result in reduced immunity of fish and higher susceptibility to parasites and diseases (Murray, 2005; Biu et al., 2014) ${ }^{[26,7]}$. 
Like humans and other animals, fishes suffer from various disease and parasite infections (Bamidele, 2015) ${ }^{[4]}$. Parasitic diseases of fish are very common all over the world and are of particular importance in the tropics ${ }^{[33]}$ Soliman \& Nasr, 2015) ${ }^{[35]}$. Various parasites are associated with $C$. gariepinus in the wild and cultured environment where they cause morbidity, mortality and economic losses in aquaculture practice in various parts of the world (Subashinghe, 1995; Biu et al., 2013) ${ }^{[37,6]}$

Parasites can be found in any fish species and within any type of aquatic system. They range from Protozoans (Flagellates, Ciliates, Apicomplexans, etc.) to Metazoans (Myxozoans, Trematodes, Cestodes, Acanthocephalans, Nematodes, and Crustaceans) ${ }^{[22]}$. Maria et al. (2005) ${ }^{[24]}$ related health condition with parasite infestation of $C$. gariepinus. Fish diseases and disease causing organisms in general are enormous in numbers. Accordingly, the agents causing fish diseases are diverse, including viruses, bacteria, fungi and parasites [32]. Parasitism is a relationship between two organisms in which one organism benefits, the parasite, while the other organism is harmed, the host animal ${ }^{[32]}$. Harm to the host can be caused by tissue damage during the parasite's various life cycle stages, which in themselves are detrimental to the host, but can also make the host more susceptible to other diseases. Parasites can also harbor bacteria or viruses and transmit them to the host organism ${ }^{[21]}$.

Parasites are common in most ecological system and all free living organisms can be potential hosts to parasites; parasitism in itself is one of the most common lifestyles on earth ${ }^{[25]}$. One reason of concern is parasites not only impact other animals but humans also. There are some parasites that are zoonotic or can be passed from animals to humans. This can occur if animals and humans are living closely in the same environment, from human consumption of animal products, or other means. Clarias gariepinusis one of the most resistant and widely accepted and highly valued fish that are been cultivated in Nigeria, therefore the need for documented research on parasites which might constitute serious problems on this fish cannot be over emphasized ${ }^{[9]}$.

There is an increasing awareness of the importance of parasitic diseases as one of the major detrimental factors in fish farming [31]. However, in Yola, there is a paucity of information on the parasitic status of Clarias gariepinus. Therefore, this study sought to determine the incidence of parasitic infection and prevalence in adult and juvenile $C$. Gariepinus in the study area with the view of identifying the parasitic load and to assess the correlation between infection, the sex, weight and length.

\section{Materials and Methods}

\subsection{Experimental Location}

Gesedaddo farm limited Yola is a private commercial fish farm located along Numan road, elevation 166 meters, location N 09- 16'32.1', E 012- 22'26.8', (Location from GPS). Clarias gariepinus is one of the most resistant and widely accepted and highly valued fish that are been cultivated in Yola and highly accepted by the consumers and marketers when it is fresh or smoked. Therefore, the need for documented research on parasites which might constitute serious problems on this fish cannot be over emphasized ${ }^{[9]}$.There is an increasing awareness of the importance of parasitic diseases as one of the major detrimental factors in fish farming [31]. However, in Yola, there is a paucity of information on the parasitic status of $C$. gariepinus.

\subsection{Experimental Design}

Fish samples were collected from the selected study area for a period of six (6) months. The fish samples were transported alive to the Department of Fisheries Laboratory, MAUTECH, Yola in an air free plastic container filled with water for identification and examination.

\subsection{Identification of Clarias gariepinus}

The fish was identified as described ${ }^{[38]}$. They have an elongated body, a soft rayed dorsal fin extending to or nearly to the caudal fin base, a soft rayed anal fin extending from just behind the anus to the caudal base, pectoral fins each with a serrated anterior bony spine, head depressed, covered largely by firmly sutured, surface sculptured bony plates forming a protective helmet, four pairs of flagellate barbells (nasals, maxillaries, inner and outer mandibular), air breathing organs derived from the 2 nd and $4^{\text {th }}$ epibranchialis within a super branchial chamber.

\subsection{Sexing of Fish}

Sexing of fish was done by physical observation of the urogenital papillae. It is long or distended in male while in the female it is round and reddish in the matured ones. Also visual observation of the gonads in male and ovaries in the female is confirmatory ${ }^{[18]}$.

\subsection{Measurement of Fish}

The total length was measured with a meter rule while the weight was measured using top loading sensitive weighing balance (Model: Mettler Toledo).

\subsection{Examination of Samples for Ecto and Endo parasites}

The external surface (skin and fins) were placed under a light microscope for examination. Gills were cut out and placed into separate Petri dishes and observed with hand lens for parasites. Parasites were collected and fixed in buffered formalin for further processing and specimen identification [31]. The fish was dissected to expose the alimentary canal. The alimentary canal was removed and sectioned into various parts; oesophagus and stomach, intestine and rectum. The gut was used for parasitic examination because this is where food is most abundant for the parasites. Each section was placed separately in Petri dishes containing 0.9\% normal saline. Each section was slit longitudinally and examined for parasites under a dissecting microscope between 10 and $30 \mathrm{X}$ magnification. The emergence of any worm was easily noticed by its wriggling movement in the saline solution under a microscope. Parasites found were counted, and thereafter fixed and preserved in 5\% formalin. Representative parasites were stained overnight with weak solution of Erlich's haematoxylin.

\subsection{Statistical Analysis}

Prevalence and Intensity of infection was calculated using simple percentage $(\%)$. Length range frequency in relation to prevalence within the samples were analysed.

Method of data collection:

1. The prevalence of parasites infection was calculated using the model

Prevalence $(\%)=\frac{\text { No of fish host infected }}{\text { Total no. of fish host Examined }} \times 100$ [9] 
2. The prevalence of parasites infection base on sex of fish was estimated using:

Prevalence $(\%)=\frac{\text { No. of a particular sex of fish infected }}{\text { Total no. of a particular sex of fish examined }} \times 100^{[15]}$

3. The intensity of parasites was estimated using model

Intensity $=$ Total no. of parasite species in a sample of fish Examined No. of fish host infected

The dependence of infection on sex was statistically determined using chi-square analysis and t-test.

\section{Results}

A total of two hundred and thirty-two (132) fish were sampled for parasitic investigation. Out of these, cultured adults (66) and cultured juveniles (66) respectively.

However, a total number of 43 adult $C$. gariepinus were infected out of which 132 parasites were identified, while in juvenile C.gariepinus, a total number of 10 fish were infected in which 30 parasites were recovered in Gesedaddo's farm.

Seven (7) classes of parasites and eleven (11) parasites species, which are namely, Piscinoodinium, (Dinoflagellata), Coccidia, Spironucleus vortens, (Flagellata), Chilodonella,
Tetrehymena, (Motile ciliate), Capillaria, Contracaecum, (Nematoda), Microsporidians, (Protozoa), Saprolegnia sp, (Oomycota), Digeneans, and Planarian (Trematoda) were recorded from the gills, stomach, intestine, and skin mucus of the cultured (Gessedado's farm) Clarias gariepinus in the research study.

\subsection{Incidence of Parasites in Adult and Juvenile Clarias gariepinus from Gesedaddo's Farm, Adamawa state}

Table 1 and 2 presented the parasitic incidence occurring in Clarias gariepinus at Gesedaddo's farm, Yola, Adamawa state. Regarding the incidence of parasites in the examined fish species, the highest number of parasites recovered in adult Clarias gariepinus at Gesedaddo's farm was found in the intestine with total number of 63 (47.73), followed by 48 (36.36) in the gill, 15 (11.36) in the stomach, and the least parasites recovered $6(4.55)$ on the skin. Therefore, the incidence of parasites in Gesedaddo's farm was higher in the intestine with 63 (47.73) and the least was recovered 6(4.55) on the skin while the highest number of parasites recovered in juvenile Clarias gariepinus was found on the skin with total number of 11 (36.67), followed by 9 (30) in the intestine, 6 (20) in the stomach, and the least parasites recovered 4 (13.33) in the gill.

Table 1: Incidence of parasites in Adult C. gariepinus in Gesedaddo's Farm

\begin{tabular}{|c|c|c|c|c|c|c|c|c|c|c|}
\hline Parasite sp & No. of fish infected & \% & Gill & \% & Skin & \% & Intestine & \% & Stomach & \% \\
\hline Spironucleus vortens & 4 & 10.53 & - & - & - & - & 16 & 12.12 & - & - \\
\hline Coccidia & 3 & 7.89 & - & - & - & - & 14 & 10.61 & - & - \\
\hline Piscinoodinium & 6 & 15.79 & 30 & 22.73 & - & - & - & - & - & - \\
\hline Tetrahymena & 2 & 5.26 & 3 & 2.27 & - & - & - & - & - & - \\
\hline Contracaecum & 3 & 7.89 & - & - & 6 & 4.55 & - & - & - & - \\
\hline Microsporidians & 14 & 36.85 & 11 & 8.33 & & & 19 & 14.39 & 15 & 11.36 \\
\hline Digeneans & 2 & 5.26 & 4 & 3.03 & - & - & - & - & - & - \\
\hline Planarian & 4 & 10.53 & - & - & - & - & 14 & 10.61 & - & - \\
\hline Total & 43 & & 48 & & 6 & & 63 & & 15 & \\
\hline
\end{tabular}

Table 2: Incidence of parasites in Juvenile C. gariepinus in Gesedaddo's Farm

\begin{tabular}{|c|c|c|c|c|c|c|c|c|c|c|}
\hline Parasite sp & No. of fish infected & $\boldsymbol{\%}$ & Gill & $\mathbf{\%}$ & Skin & $\%$ & Intestine & \% & Stomach & \% \\
\hline & & & & & & & & & & \\
\hline Chilodonalla & 3 & 30 & - & - & 9 & 30 & - & - & - & - \\
\hline Capillaria & 1 & 10 & - & - & - & - & 2 & 6.67 & - & - \\
\hline Saprolegnia sp & 1 & 10 & - & - & 2 & 6.67 & - & - & - & - \\
\hline Microsporidians & 5 & 50 & 4 & 13.33 & - & - & 7 & 23.33 & 6 & 20 \\
\hline Total & 10 & & 4 & & 11 & & 9 & & 6 & \\
\hline
\end{tabular}

\subsection{Prevalence of Parasites in Cultured Adult Clarias gariepinus based on Sex}

Table 3 represent the prevalence of parasites in cultured Clarias gariepinus fish samples. Out of the examined Clarias gariepinus, fish were found infected with parasites with an infection rate that reached $75.00 \%$ in female fish and $36.67 \%$ in male cultured system. The Infection rate and intensity of the parasites were higher in the adult female fish than in the male cultured Clarias gariepinus with the high rate of $75.00 \%$ to $36.67 \%$ respectively. The mean parasite intensity was (3.36). The chi square value shows that there is no significant difference $(p>0.05)$ between the prevalence and intensity of parasite infection in adult $C$. gariepinus based on sex.

\subsection{Prevalence of Parasites in Cultured Juvenile Clarias gariepinus based on Sex}

Table 4 represent the prevalence of parasites in the cultured (Gessedado's Farm) juvenile Clarias gariepinus fish samples. Out of the examined Clarias gariepinus, fish were found infected with parasites with an infection rate that reaches $15.91 \%$ in female fish while $13.64 \%$ of males were infected in the Gessedado's farm.

The mean parasite intensity was (3.10). The chi square value shows that there was no significant difference $(p>0.05)$ between the prevalence and intensity of parasite infection in juvenile $C$. gariepinus based on sex. 
Table 3: Prevalence and Intensity of Parasite Infection in adult Clarias gariepinus based on Sex

\begin{tabular}{|c|c|c|c|c|c|c|c|}
\hline Location & Sex & $\begin{array}{c}\text { Number } \\
\text { Examined }\end{array}$ & $\begin{array}{c}\text { No of Fish } \\
\text { Infected }\end{array}$ & $\begin{array}{c}\text { Total no of } \\
\text { Parasites }\end{array}$ & $\begin{array}{c}\text { Prevalence } \\
(\boldsymbol{\%})\end{array}$ & $\begin{array}{c}\text { Intensity of } \\
\text { Parasite }\end{array}$ & $\begin{array}{c}\text { Mean Parasite } \\
\text { Intensity }\end{array}$ \\
\hline Gessedado Farm & Male & 30 & 11 & 34 & 36.67 & 3.09 & \\
\hline & Female & 36 & 27 & 98 & 75.00 & 3.63 & \\
\hline
\end{tabular}

Table 4: Prevalence and intensity of parasite infection in Juvenile Clarias gariepinus based on Sex

\begin{tabular}{|c|c|c|c|c|c|c|c|}
\hline Location & Sex & $\begin{array}{c}\text { No of Fish } \\
\text { Examined }\end{array}$ & No of Fish Infected & $\begin{array}{c}\text { Total No of Parasites } \\
\text { recovered }\end{array}$ & $\begin{array}{c}\text { Prevalence } \\
(\%)\end{array}$ & $\begin{array}{c}\text { Intensity of } \\
\text { Parasite }\end{array}$ & $\begin{array}{c}\text { Mean Parasite } \\
\text { Intensity }\end{array}$ \\
\hline Gesedaddo Farm & Male & 22 & 3 & 10 & 13.64 & 3.33 & \\
\hline & Female & 44 & 7 & 20 & 15.91 & 2.86 & 3.10 \\
\hline
\end{tabular}

$\chi^{2}=3.709788 ; \mathrm{p}>0.01 ; \mathrm{df}=1$, Key 2 = Chi square Df, degree of freedom P, probability level

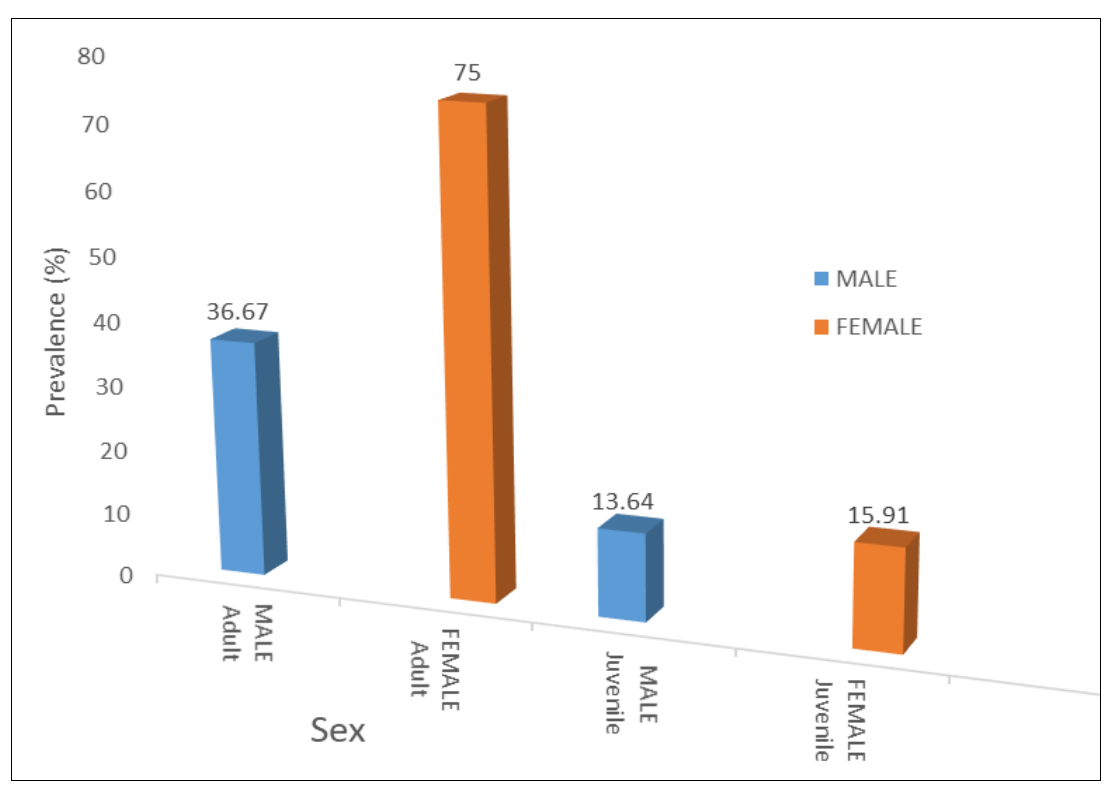

Fig 1: Sex Variation in Prevalence (\%) of Parasitic Infection of Culture Clarias gariepinus

3.4 Prevalence and intensity of parasite infection in Adult Clarias gariepinus based on Total length in Gesedaddo's farm

Table 5 presented the prevalence and intensity of parasitic infection in adult Clarias gariepinus based on total length in
Gessedado farm. The highest prevalence of $100 \%$ were found within the length range of 26.30-28.30, 28.31-30.31, and $36.35-38.35 \mathrm{~cm}$ respectively while the least prevalence was recorded for the total length within the range of 32.33-34.33 with the prevalence rate of $33.33 \%$.

Table 5: Prevalence and intensity of parasite infection in Adult Clarias gariepinus based on Total length in Gesedaddo's farm

\begin{tabular}{|c|c|c|c|c|c|}
\hline Total length (cm) & No of Fish Examined & No of Fish Infected & Total No of Parasites recovered & Prevalence (\%) & Intensity of Parasite \\
\hline $26.30-28.30$ & 3 & 3 & 8 & 100.00 & 2.67 \\
\hline $28.31-30.31$ & 2 & 2 & 6 & 100.00 & 3.00 \\
\hline $30.32-32.32$ & 10 & 7 & 32 & 70.00 & 4.57 \\
\hline $32.33-34.33$ & 15 & 5 & 19 & 37.33 & 3.80 \\
\hline $34.34-36.34$ & 8 & 3 & 8 & 100.00 & 2.67 \\
\hline $36.35-38.35$ & 12 & 12 & 44 & 37.50 & \\
\hline $38.36-40.36$ & 16 & 6 & 15 & & 2.50 \\
\hline Total & 66 & 38 & 112 & \\
\hline
\end{tabular}

3.5 Prevalence and intensity of parasite infection in Adult Clarias gariepinus based on Body Weight in Gesedaddo's farm

The prevalence and intensity of parasite infection in adult Clarias gariepinus based on body weight in Gessedado is presented in Table 6 below. The highest prevalence of $83.33 \%$ was recorded within the weight range of 460.07$500.07 \mathrm{~g}$ followed by the weight range of $360.05-400.05 \mathrm{~g}$ with the prevalence rate of $70.00 \%$ while the Clarias gariepinus within the weight range of 260.03-300.03 were not infected therefore has $0 \%$ prevalence rate.
3.6 Prevalence and intensity of parasite infection in Juvenile Clarias gariepinus based on Total length in Gesedaddo's farm

Table 8 represent the prevalence and intensity of parasitic infection in adult Clarias gariepinus based on total length in Gessedado's farm.

The highest prevalence of $26.67 \%$ were found within the length range of 10.91-13.90 while the least prevalence was recorded for the total length within the range 7.90-10.90 with the prevalence rate of $11.54 \%$. 
Table 6: Prevalence and intensity of parasite infection in Adult Clarias gariepinus based on Body Weight in Gesedaddo Farm

\begin{tabular}{|c|c|c|c|c|c|}
\hline Body weight (g) & No of Fish Examined & No of Fish Infected & Total No of Parasites recovered & Prevalence (\%) & Intensity of Parasite \\
\hline $100.00-150.00$ & 10 & 6 & 20 & 60.00 & 3.33 \\
\hline $160.01-200.01$ & 8 & 5 & 10 & 62.50 & \\
\hline $210.02-250.02$ & 6 & 4 & 16 & 66.67 & 2.00 \\
\hline $260.03-300.03$ & 4 & 0 & 0 & 0.00 & 4.00 \\
\hline $310.04-350.04$ & 7 & 3 & 9 & 42.85 & 0.00 \\
\hline $360.05-400.05$ & 10 & 7 & 26 & 70.00 & 3.00 \\
\hline $410.06-450.06$ & 9 & 3 & 13 & 33.33 & 3.71 \\
\hline $460.07-500.07$ & 12 & 10 & 38 & 83.33 & 4.33 \\
\hline
\end{tabular}

Table 7: Condition factor of Adult C. gariepinus in Gessedado farm

\begin{tabular}{|c|c|c|}
\hline \multicolumn{3}{|c|}{ Adult: Gessedado } \\
\hline Mid Body Weight $(\mathbf{g})$ & Mid Total Length $(\mathbf{c m})$ & Condition factor $\mathbf{( k )}$ \\
\hline 175.11 & 29.31 & 0.7 \\
\hline 330.04 & 34.34 & 0.82 \\
\hline 455.07 & 38.36 & 0.81 \\
\hline
\end{tabular}

Table 8: Prevalence and intensity of parasite infection in Juvenile Clarias gariepinus based on Total Length in Gessedado

\begin{tabular}{|c|c|c|c|c|c|}
\hline Total Length $\mathbf{( c m )}$ & No of Fish Examined & No of Fish Infected & Total No of Parasites recovered & Prevalence (\%) & Intensity of Parasite \\
\hline $7.90-10.90$ & 26 & 3 & 5 & 11.54 & 1.67 \\
\hline $10.91-13.90$ & 15 & 4 & 8 & 26.67 & 2.0 \\
\hline $13.91-16.90$ & 25 & 3 & 17 & 12.00 & 5.67 \\
\hline
\end{tabular}

3.6 Prevalence and intensity of parasite infection in Juvenile Clarias gariepinus based on Body Weight in Gesedaddo Farm

The prevalence and intensity of parasite infection in Juvenile Clarias gariepinus based on body weight in Gessedado's farm is presented in Table 9 below. The highest prevalence of
$33.33 \%$ was recorded within the weight range of 60.24 $70.24 \mathrm{~g}$ followed by the weight range of 50.23-60.23g with the prevalence rate of $25.00 \%$ while the Clarias gariepinus within the weight range of 30.22-40.22 were not infected therefore has $0 \%$ prevalence rate.

Table 9: Prevalence and intensity of parasite infection in Juveniles Clarias gariepinus based on Body Weight in Gessedado's farm

\begin{tabular}{|c|c|c|c|c|c|}
\hline Body Weight (g) & No of Fish Examined & No of Fish Infected & Total No of Parasites recovered & Prevalence (\%) & Intensity of Parasite \\
\hline $10.20-20.20$ & 17 & 1 & 2 & 5.88 & 2.0 \\
\hline $20.21-30.21$ & 14 & 2 & 5 & 14.29 & 2.5 \\
\hline $30.22-40.22$ & 8 & 0 & 0 & 0.00 & 7.69 \\
\hline $40.23-50.22$ & 13 & 1 & 3 & 25.00 & 3.0 \\
\hline $50.23-60.23$ & 16 & 4 & 13 & 33.33 & 3.25 \\
\hline $60.24-70.24$ & 6 & 2 & 8 & 4.0 \\
\hline
\end{tabular}

Table 10: Condition factor of Juvenile C. gariepinus in Gessedado's farm

\begin{tabular}{|c|c|c|}
\hline \multicolumn{3}{|c|}{ Juvenile: Gessedado } \\
\hline Mid Body Weight (g) & Mid Total Length $(\mathbf{c m})$ & Condition factor $(\mathbf{k})$ \\
\hline 27.21 & 28.31 & 0.12 \\
\hline 57.74 & 33.33 & 0.16 \\
\hline 88.26 & 38.36 & 0.16 \\
\hline
\end{tabular}

\subsection{Burden of Parasites in Adult and Juvenile Clarias gariepinus in Gesedaddo's Farm}

Table 11 presented the burden of parasites in adult and Juvenile Clarias gariepinus in Gessedado farm. The total burden of parasites of $132(100 \%)$ was recorded from adults and a total of $30(100 \%)$ was recorded from Juvenile which give the sum total of 162 parasites load. Among the class of parasites recovered, it was recorded that the burden of parasites recovered in the class nematode were 2 (6.67) and 6 (4.55), trematode $0(0.0)$ and 18 (13.64), dinoflagellates 0 (0.0) and 30 (22.73), flagellates $0(0.0)$ and 30 (22.73), Protozoans, 17(56.67) and 45(34.09), Motile ciliates 9(30) and $0(0.0)$, Sessile ciliates $0(0.0)$ and 3(2.27) in juveniles and adult fish respectively.

Therefore, the highest burden of parasites occurred most in the class protozoan with $45(34.09 \%)$ and 17 (56.67) in adult and Juvenile C.gariepinus respectively.
Table 11: Burden of Parasites in Adult and Juvenile Clarias gariepinus in Gesedaddo's Farm

\begin{tabular}{|c|c|c|c|}
\hline Class of parasite & Juveniles & Adults & Total \\
\hline Nematode & $2(6.67)$ & $6(4.55)$ & $10(6.17)$ \\
\hline Trematode & $0(0.0)$ & $18(13.64)$ & $18(11.11)$ \\
\hline Dinoflagellates & $0(0.0)$ & $30(22.73)$ & $30(18.52)$ \\
\hline Flagellates & $0(0.0)$ & $30(22.73)$ & $30(18.52)$ \\
\hline Protozoans & $17(56.67)$ & $45(34.09)$ & $62(38.27)$ \\
\hline Motile ciliates & $9(30)$ & $0(0.0)$ & $9(5.56)$ \\
\hline Sessile ciliates & $0(0.0)$ & $3(2.27)$ & $3(1.85)$ \\
\hline Total & $30(100)$ & $132(100)$ & $162(100)$ \\
\hline
\end{tabular}

NB: Data in parenthesis are in percentages

\section{Discussion}

4.1 Incidence of Parasites in Adult Clarias gariepinus in Gesedaddo's Farm of Adamawa State

The overall prevalence of parasites in this study was high 
(132) in adult Clarias gariepinus compare to the juveniles which was similar to what was recorded in the same area [9] ${ }^{[10]}$. Other researchers in Nigeria ${ }^{[3]}$ recorded a prevalence rate of $59.8 \%,{ }^{[34]}$ reported a prevalence rate of $75 \%,{ }^{[29]}$ reported a prevalence of $63.0 \%$ in wild population of $C$. gariepinus and $59.8 \%$ in cultured C. gariepinus in Jos, Plateau State. Difference in prevalence of parasites in fish may be due to many factors. Parasitism differs in various aquatic ecosystems and this is determined by the interaction between biotic and abiotic factors. Fish species in good environmental conditions rarely come down with diseases ${ }^{[30]}$. Reports have shown that helminths are generally found in all freshwater fishes, with their prevalence and intensity dependent on factors of parasite species and their biology, host and its feeding habits, physical factors and hygiene of the water body, and presence of intermediate hosts where necessary ${ }^{[11][36]}{ }^{[16]}$. It is worthy to note that infection rates vary greatly from one area to another, and this may be associated with the fact that a number of factors like availability of intermediate hosts, and susceptibility of definite hosts amongst others determine to a large extent the rate of infection ${ }^{[27]}$.

\subsection{Prevalence and Intensity of Parasite Infection in Clarias gariepinus based on Sex}

From this study, sampled female fish were more parasitized than males. Females had higher incidence rate and prevalence rate than males. This is consistent with the findings of ${ }^{[12]}$ who reported differences in the incidence of infestation between male and female fish, which may be due to differential feeding either by quantity or quality of feed, or as a result of different degrees of resistance to infection ${ }^{[13]}$. Also reported that due to the physiological state of the female, most gravid females could have reduced resistance to infection by parasites.

The result obtained in this study revealed varying degree of prevalence and intensity rate of parasitic infection in the studied area at Gessedado's Farm. The sex ratio found in this study indicated that more females than males occurred in the samples fish population in both location, similarly a higher number of helminth parasites were found in females than the males. There was a significant difference in the prevalence of infection between the males and the females. This observation could also be due to the fact that there were simply more females available for infestation ${ }^{[8]}$.

\subsection{Prevalence and intensity of parasite infection in} Clarias gariepinus based on Length in Gessedado Farm

It was observed that fishes total length range of 26.30$28.30 \mathrm{~cm}, 28.31-30.31 \mathrm{~cm}$ and $36.35-38.35 \mathrm{~cm}$ had the highest incidence rate of parasites at $100 \%$ compare to those with length of $30.32-32.31 \mathrm{~cm}, 32.33-34.33 \mathrm{~cm}$, and $34.34-36.34 \mathrm{~cm}$ $(70 \%, 33.33 \%$, and $37.50 \%$ respectively) and longer fish of $36.35-38.35 \mathrm{~cm}(100 \%)$. The prevalence of infection was higher in short fish than in long fish for adult Clarias gariepinus. This means that the adult fish were more infested than the juvenile ones. This could be attributed to the fact adult fish have less immunity against parasites whereas juvenile fish have fully developed immunity against parasitic infestation. This observation is not in consonance with ${ }^{[1]}$ who investigated the incidence and pathogenesis of Chrostomium tilapiae in Oyo State farms and reported that juvenile fish were more susceptible to $C$. tilapiae infection. This is also not in consonance with ${ }^{[2]}$ who reported that the smaller fish were more infested than the bigger ones. But ${ }^{[20]}$ studied some parasites of culture fish and reported that there was a gradual increase in the percentage infection with increase in weight. From this study, female fish were more parasitized than males. Females had higher incidence rate than males ${ }^{[13]}$. Also reported that due to the physiological state of the female, most gravid females could have reduced resistance to infection by parasites.

4.4 Prevalence and intensity of parasite infection in Clarias gariepinus based on Weight in Gessedado's Farm

In relation to weight, weight range of 460.07-500.07grams had the highest incidence rate of parasites at $83.33 \%$.This means that the adult fish were more infested than the juvenile ones. This could be attributed to the fact adult fish have less immunity against parasites whereas juvenile fish have fully developed immunity against parasitic infestation. This observation is not in consonance with ${ }^{[1]}$ who investigated the incidence and pathogenesis of Chrostomium tilapiae in Oyo State farms and reported that juvenile fish were more susceptible to $C$. tilapiae infection. This is also not in consonance with ${ }^{[2]}$ who reported that the smaller fish were more infested than the bigger ones. But ${ }^{[20]}$ studied some parasites of culture fish and reported that there was a gradual increase in the percentage infection with increase in weight. From this study, female fish were more parasitized than males. Females had higher incidence rate than males. This is consistent with the findings of ${ }^{[12]}$ who reported differences in the incidence of infestation between male and female fish, which may be due to differential feeding either by quantity or quality of feed, or as a result of different degrees of resistance to infection ${ }^{[13]}$. Also reported that due to the physiological state of the female, most gravid females could have reduced resistance to infection by parasites.

\subsection{Condition Factor and Parasitic Infection Occurrence}

The condition factor of adult and juvenile Clarias gariepinus were below one. This is an indication of heavy parasitic infection. And drops in condition factor values may indicate the reproductive period and/or changes in the foraging habits of certain species ${ }^{[14,5]}$. Stated that the value of the condition factor is influenced by age of fish, sex, season, stage of maturation, fullness of gut, type of food consumed, amount of fat reserve and degree of muscular development. With females, the condition factor value will decrease rapidly when the eggs are shed

According to ${ }^{[5]}$ a Condition Factor value of 0.80 indicates an extremely poor fish, resembling a barracuda (big head and narrow, thin body) while a value of 1.20 indicates a good fish. Condition factors are believed to be good indicators of the general well-being or fitness of fish populations and are often used as indicators of pollutant exposure and the effect thereof ${ }^{[19]}$. Since parasites are constantly in contact with the external environment, they tend to reduce in diversity and abundance when water is heavily polluted and higher numbers of ectoparasites should be expected in good quality water ${ }^{[23]}$. The number of endoparasites, on the other hand, tends to increase in polluted water. This might be due to a lowered immune system and resistance of the fish due to continuous stress conditions.

Water quality parameters are either a direct or indirect factor contributing to the influence on fish growth and reproduction, but not to the pathological effects ${ }^{[39]}$. Temperature is one of the most important factors affecting the physiology, growth, reproduction and metabolism of fish species. 


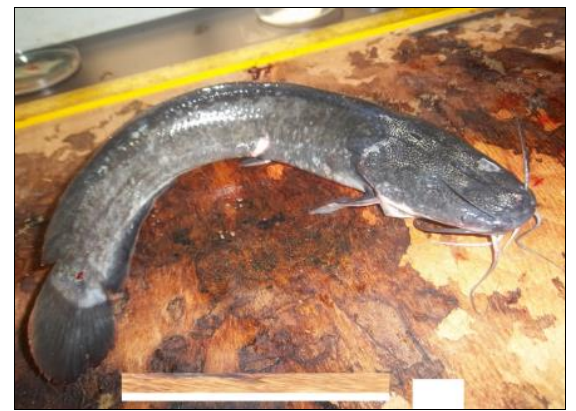

Plate 1: Adult Clarias gariepinus placed on adissecting board after measurement and weighing for dissection

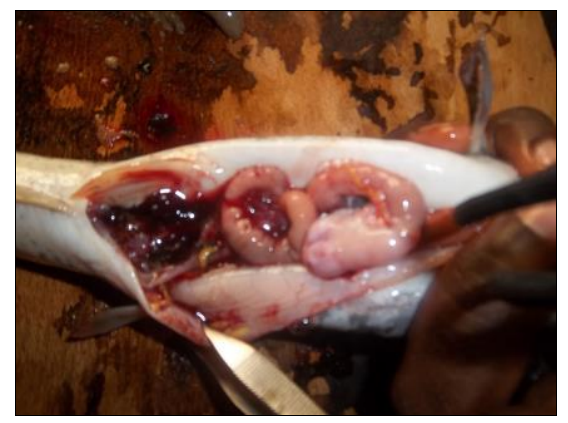

Plate 2: Internal organ of adult Clarias gariepinus dissection indicating the stomach, intestine

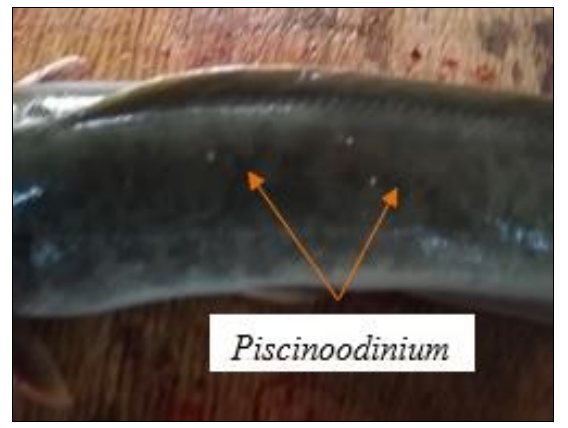

Plate 3: Piscinoodinium (Dinoflagellate) found on the skin of adult Clarias gariepinus
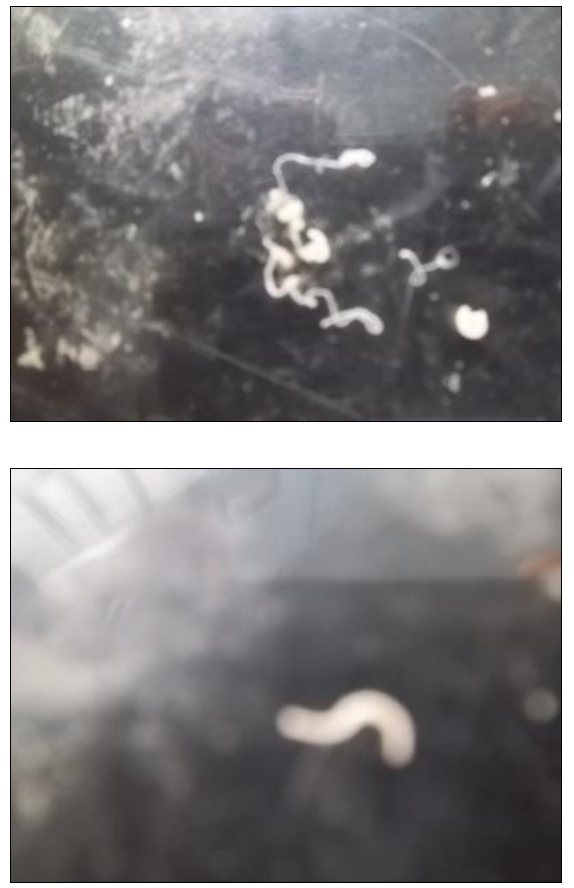

Plate 4: Capillaria parasites recovered from the stomach and intestine of C. gariepinu

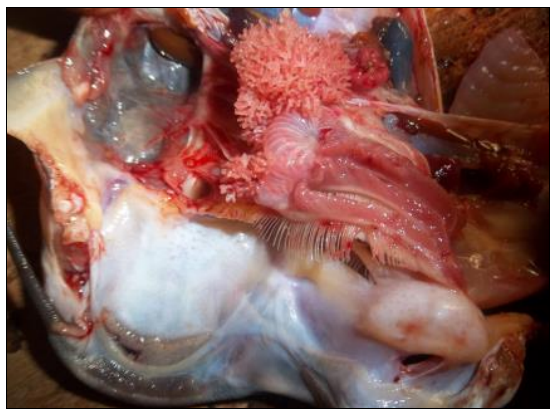

Plate 6: Piscinoodinium (Dinoflagellate) found on the gill of adult Clarias gariepinus

\section{Conclusion}

The overall prevalence of parasites in this study was high in adult Clarias gariepinus compare to the juveniles which was similar to what was recorded in the same area ${ }^{[9,10]}$.

In relation to weight, weight range of 460.07-500.07grams had the highest incidence rate of parasites at $83.33 \%$.This means that the adult fish were more infested than the juvenile ones. This could be attributed to the fact adult fish have less immunity against parasites whereas juvenile fish have fully developed immunity against parasitic infestation.

In relation to sex, the Infection rate and intensity of the parasites were higher in the adult female fish than in the male cultured Clarias gariepinus with the high rate of $75.00 \%$ to $36.67 \%$ respectively. Among the class of parasites recovered, it was recorded that the highest burden of parasites was discovered most in the class protozoan.

\section{Acknowledgement}

I am grateful to God Almighty for making this work a success. My profound gratitude goes to my parents Mr. and Mrs. Fhatso T.N Tukura and Late Prof. Idama Ademu, Prof. G.T Gungula, Prof. A.O Sogbeson, Prof. S.N Solomon, for their tireless effort towards the success of this work.

\section{References}

1. Adeyemo AO. Incidence and pathogenesis of Chrostomum tilapia: A trematode parasite of Tilapia $(O$. reochromis niloticus) Unpublished Ph.D. Thesis. University of Ibadan. 2001, 224.

2. Akinsanya B, Otubanjo OA, Hassan AA. Helminth parasites of Malapterurus CDC-INFO (800-232-4636) TTY. 2007;(888):232-6348. Contact CDC-INFO. http://www.cdc.gov/dpdx/, retrieved 12-07-2016.

3. Anosike JC, Omoregie E, Ofojekwu PC, Nweke IE. A survey of Helminths parasites of Clarias gariepinus in Plateau State. Nigeria Journal of Aquatic Sciences. 1992;7(1):39-43.

4. Bamidele A. A two fish species study of the parasitic helminth fauna of Synodontis filamentosus (Boulenger, 1901) and Calamoichthys calabaricus (SMITH, 1865) From Lekki Lagoon, Lagos, Nigeria. Ife Journal of Science. 2015;17(1):97-108.

5. Barnham C, Baxter A. Fisheries Notes: Condition Factor, K, for Salmonid Fish. State of Victoria, Department of Primary Industries. 1998.

6. Biu AA, Akorede GJ. Prevalence of endoparasite of Clarias gariepinus (Burrell, 1822) in Maiduguri, Nigeria. Nigerian Journal of Fisheries and Aquaculture. 2013;1(1):1-6

7. Biu AA, Diyaware MY, Yakaka W, Rita DJ. Incidence of Parasites of Clarias gariepinus (Burchell, 1822) Caught 
from Lake Alau, Maiduguri, Borno State, Nigeria. Nigerian Journal of Fisheries and Aquaculture. 2014;2(1):74-80.

8. Byrne CJ, Holland C, Tully O. Metazoan Parasites Community Structure of Sea Trout on the West Coast of Ireland. Journal of Fish Biology. 1999;55:127-134. http://dx.doi.org/10.1111/j.1095-8649.1999.tb00662.x

9. Dankishiya AS, Zakari M. Study on the gastrointestinal helminth parasites of Clarias gariepinus (Tuegels). In Gwagwalada, FCT, Nigeria. BEST Journal. 2007;4(2):79-81. DOI: $10.2307 / 1444352$. JSTOR1444352

10. Dan-kishiya AS, Oboh A, Usman BI. The prevalence of Helminth parasites in the gastro-intestinal tract of wild African sharptooth catfish Clarias gariepinus (Siluriformes: Clariidae) in Gwagwalada, Nigeria. Research Journal of the Costa Rican Distance Education University. 2013;5(1):83-87.

11. Doreen ZM, Chakanesta C, Phumuzile Y. Observation on the helminth parasite of fish in Insukamini Dam, Zimbabwe. Research Journal of Agriculture and Biological Science. 2009;5(5):782-785.

12. Emere MC. Parasitic infection of the Nile prech (Lates niloticus) in River Kaduna. Journal of Aquatic Sciences. 2000;31:34-45, 17.

13. Emere MC, Egbe NEL. Protozoan parasites of Synodontis clarias (A freshwater fish) in river Kaduna. BEST Journal. 2006;3(3):58 64.F.S), Washington DC.

14. Gomiero LM, Braga FMS. The condition factor of fishes from two river basins in Sao Paulo state, Southeast of Brazil. Acta Scientiarum. 2005;27:73-78.

15. Goselle ON, Shir GI, Udeh EO, Abelau M, Imandeh GN. Helminth parasites of Clarias gariepinus and Tilapia zilli at Lamingo Dam, Jos. Nigeria. Science World Journal. 2008;3(4):23-27.

16. Hussen A, Tefera M, Astrate S. Gastrointestinal helminth parasites of Clarias gariepinus (catfish) in Lake Hawassa, Ethiopia. Scientific Journal of Animal Science. 2012;1(4):131-136.

17. Ibeun MO. Information for Fisheries Management in Nigeria; The role of Libraries and Networking. National Institute for Freshwater Fisheries Research, 2006.

18. Imam TS, Dewu RA. Survey of Piscine ecto and intestinal parasites of Clarias sp. sold at Galadima road fish market, Kano metropolis, Nigeria. Bioscience Research Communication. 2010;22(4):209.

19. Kloepper-Sams PJ, Benton E. Exposure of ®sh to biologically-treated bleached kraft millefuent. 2. Induction of hepatic cytochrome P4501A in mountain white $\AA$ sh (Prosopium williamsoni) and other species. Environ. Toxicol. Chem. 1994;13:1483 \pm 96 .

20. Kudoro OA. Some parasites of cultured fishes of Mobolaji Fish Farm. Ado-Odo Unpublished M.Sc. Thesis University of Ibadan, Nigeria. 1995, 88P.

21. Lasee BA. Introduction to fish health management. Onalaska, WI: U.S. Fish and Wildlife Service, 1995.

22. Lewis GW. Angleres guide to fish diseases and parasites. Circular 772. The cooperative Extensive Service, University of Georgia, college of Agricultural and Environmental sciences, 1991.

23. Luus-Powell WJ, Jooste A, Hattingh HE. Parasites of Clarias gariepinusas bio-indicators of pollution. Journal of the South African Veterinary Association. 2005;76(3):181.
24. Maria JTR, Nilza NF, Jose LL. Parasitological and haematological analysis of Nile tilapia, Oreochromis niloticus Linnaeus, 1757 from Guarapiranga reservoir, Sao Paulo state, Brazil. Acta Sci. Biol. Sci. 2005;27:231237.

25. Madanire Moyo G, Barson M. Diversity of metazoan parasites of the African catfish Clarias gariepinus as indicators of pollution in a subtropical African river system', Journal of Helminthology. 2010;84:216-227. http://dx.doi.org/10.1017/S0022149X09990563, PMid:19761628

26. Murray AG. A framework for understanding the potential for emerging diseases. In: aquaculture. Preventive Veterinary Medicine. 2005;67(2-3):223-235.

27. Obano EE, Ezeri GNO, Aniyie UK. Studies on the parasitic infections in fishes in Ovia River at Ikoro, OviaSouth West Local Government Area of Edo State, Nigeria. Bioscience Research Communications. 2010b;22(3):137.

28. Obano EE, Odiko AE, Edoh DO. Helminthes parasitic infection of fishes from Okhuaihe river Benin City, Nigeria. Bioscience Research Communications. 2010a;22(3):129.

29. Onwuliri COE, Mgbemena MO. The parasite fauna of some fresh water fish from Jos, Plateau State, Nigeria. Journal of Applied Fisheries and Hydrobiology. 1987;2(1):33-37.

30. Oswald E, Hulse JE. Fish aquaculture and fish disease in South East Africa, Report of a workshop held in Jakarta, Indonesia. 1982, 79.

31. Paperna I. Parasites, Infections and Diseases of Fish in Africa: An update. FAO/CIFA Technical paper. 1996, 31.

32. Roberts LS, Janovy Jr J. Foundations of Parasitology (Seventh ed.). New York: McGraw Hill. 2005.

33. Roberts LS, Janovy J (Jr.). Foundations of Parasitology, 8th edition. McGraw-Hill International Editions, Boston. 2009, 502.

34. Salawu MT, Morenikeji OA, Sowunmi AA, Odaibo AB. Comparative survey of helminth parasites of Clarias gariepinus and Clarias pachynema from the Ogun River and Asejire Dam in south-west Nigeria, International Journal of Fisheries and Aquaculture. 2013;5(1):7-11.

35. Soliman NF, Nasr SM. Metal contents in common edible fish species and evaluation of potential health risks to consumers. Journal of Coastal Life Medicine. 2015;3(12):956-961.

36. Shukerova S, Kirin D, Hanzelova V. Endohelminth communities of the perch, Perca fluviatilis (Perciformes, Percidae) from Srebama Biosphere Reserve, Bulgaria. Helminthologia. 2010;42(2):99-104.

37. Subashinghe R. Diseases control and health management in aquaculture. FAO Aquacul. Newsl. 1995;9:8-11.

38. Teugels CG. A systematic revision of the African species of the genus Clarias (Pisces: Clariidae) Annales Musee Royal de l'Afrique Centrale. 1986;247:1-199.

39. Van As J, Basson L. Checklist of freshwater fish parasites from southern Africa. South African Journal of Wildlife Research. 1984;14:49-61. 